УДК 577.158:636.52/58:612.35:612.015.6

(C) 2014

Костюк I. О., кандидат сільськогосподарських наук

Харківська державна зооветеринарна академія

\title{
ОСОБЛИВОСТІ ВИКОРИСТАННЯ СУКЦИНАТУ ЯК ЕНЕРГЕТИЧНОГО СУБСТРАТУ ТКАНИННОГО ДИХАННЯ ЗА УМОВ НАКОПИЧЕННЯ ВІТАМІНУ Е В ПЕЧІНЦІ КУРЕЙ
}

\section{Рецензент - доктор біологічних наук, професор М. М. Лемешева}

У зв'язку із застосуванням бурштинової кислоти (сукцинату) як фактора метаболічної корекції в раціонах тварин та у ветеринарній медицині, актуальним є дослідження особливостей використання цієї речовини як енертетичного субстрату тканинного дихання. Важливим для ефективного застосування метаболічної корекиії є вивчення впливу вітаміну $E$ як мембранотропного фактора - на окиснення сукцинату мітохондріями печінки. Встановлено стимуляиію вільного окиснення сукичинату в мітохондріях печінки під дією високих доз вітаміну Е у раціоні курей, щуо важливо враховувати в разі можливого сумісного застосування вітаміну $E$ i сукцинату, як енертотропних факторів метаболічної корекиії у птиці.

Ключові слова: бурштинова кислота, вітамін E, тканинне дихання, мітохондрії, окислювальне фосфорилювання, печінка, сукиинат.

Постановка проблеми. Сукцинат (бурштинова кислота) - проміжний продукт метаболізму у всіх клітинах, які мають мітохондріальний комплекс ферментів ЦТК і тканинного дихання. Сукцинат як енергетичний субстрат окислюється ферментом сукцинатдегідрогеназою (КФ 1.3.5.1), віддаючи електрони й протони у дихальний ланцюг (ДЛ). У результаті такого окиснення однієї молекули сукцинату утворюється дві молекули АТФ. Процеси дихання та окиснювального фосфорилювання здійснюються в мембранах мітохондрій, що обумовлює їх високу чутливість до різних ендо- та екзогенних мембранотропних факторів. Зокрема, вітамін Е як антиоксидант впливає на структуру i функціональну активність мембран. Взаємодіючи з вільними радикалами [12], вітамін Е регулює обмін ліпідних компонентів біологічних мембран, забезпечує функціонування внутрішньоклітинних мембранних ферментних систем.

Аналіз основних досліджень і публікацій, у яких започатковано розв'язання проблеми. Встановлено, що застосування добавок вітаміну Е курям-несучкам позитивно впливає на реакції тканинного дихання в мітохондріях печінки [10]. Оскільки процеси ПОЛ і тканинне дихання взаємозв'язані, то й антиоксидантна дія $\alpha$-токоферолу прямо або побічно відображається на функціонуванні дихальних комплексів. У літературі мало даних про вплив вітаміну Е на тканинне дихання при Е-гіпервітамінозі. За результатами досліджень Higdon J. та співавт. [11] повідомляється, що вітамін Е вже в п'ятикратній дозі здійснює захисний ефект на стінки кровоносних судин. Нині питання щодо застосування вітаміну $\mathrm{E}$ як антиоксиданту 3 лікувальною метою $є$ предметом дискусій і активних досліджень. Так, у роботі [10] повідомляється, що застосування вітаміну Е та іншого антиоксиданту за новоутворень у мишей сприяє активному росту злоякісних пухлин і погіршує стан організму. Вітамін Е застосовують як харчову добавку в дієті людей. Альфа-токоферол використовують у тваринництві як компонент комбікормів, лікувальний i профілактичний препарат, засіб метаболічної корекції.

Бурштинова кислота (завдяки своїм антиоксидантним властивостям і участі у ключових енергетичних процесах в клітині [7]) активно використовується в медицині [8], у сільському господарстві [9], у ветеринарній практиці з метою корекції обміну речовин $[1 ; 6]$. Згідно з сучасною медичною концепцією, що формується, традиційні лікувально-профілактичні раціони харчування, функціональні харчові продукти, нутрицевтики і фармаконутрієнти відносяться до метаболічної терапії. Так, бурштинова кислота застосовується в якості протистресового засобу, має імуномоделюючу дію, а також відома своїми антигіпоксичними властивостями [1]. У птиці сукцинат окислюється активніше порівняно 3 іншими субстратами тканинного дихання, в 1,52 рази швидше, ніж 2-оксоглутарат.

Фермент СДГ є одним зі структурних компонентів дихального ланцюга i зв'язаний із внутрішньою мембраною мітохондрій. Цей фермент має великий запас каталітичної активності, яка може бути реалізована як у фізіологічних, так і екстремальних станах організму. СДГ, будучи одночасно ферментом ЦТК і дихального ланцюга, виконує регуляторні функції в системі енергетичного мета- 


\section{ВЕТЕРИНАРНА МЕДИЦИНА}

болізму клітини. Відомо, що сукцинат окислюється в екстремальних умовах, за яких використання НАД-залежних субстратів неможливе [7].

Важливо, що сукцинат і вітамін Е - це речовини органічного походження, природні життєво необхідні компоненти клітин. Сукцинат, як проміжний продукт ЦТК і субстрат клітинного дихання, а також альфа-токоферол, як антиоксидант і мебранотропний фактор, можуть бути цілком впевнено зараховані до енерготропних речовин. Енерготропні препарати (в силу своєї здатності впливати на функцію мітохондрій) $є$ патогенетично обгрунтованими за різних станів, що призводять до розвитку первинних і вторинних мітохондріальних порушень [8]. Отже, корекція метаболізму на рівні енергетичних процесів у мітохондріях за допомогою субстратних або мембранотропних речовин може здійснюватися природним шляхом. У зв'язку з цим актуальним $\epsilon$ дослідження впливу токоферолу на процеси використання сукцинату у мітохондріях, якщо ці речовини додатково вводять в організм у вигляді лікувальних і профілактичних препаратів або добавок у складі раціону.

У даному експерименті енергетичні процеси в мітохондріях вивчали за умови створення підвищеної концентрації вітаміну Е в печінці.

Метою роботи є дослідження особливостей окиснення сукцинату в мітохондріях печінки курей під дією підвищених доз вітаміну Е.

Завдання досліджень: визначити показники окиснення сукцинату мітохондріями печінки курей різного віку за таких умов: 1) створення запасу вітаміну $\mathrm{E}$ в печінці курей за рахунок збагачення раціону; 2) накопичення вітаміну $\mathrm{E}$ в печінці отриманих курчат за рахунок високого вмісту в яєчному жовтку; 3) короткочасне підвищення концентрації вітаміну Е в печінці після його перорального введення в організм курчат.

Матеріали та методи досліджень. В експерименті використовували курей-несучок віком
180 днів, яким упродовж 40 і 60 днів додавали до раціону вітамін $\mathrm{E}$ (олійний розчин альфатокоферилацетату). Було сформовано 4 групи птиці: I - стандартний раціон, рекомендована доза вітаміну Е складала 10 мг/кг [5]. ; II група не отримувала добавки вітаміну E; III група доза вітаміну Е 100 мг/кг; IV група - доза вітаміну Е 200 мг/кг. Групи курчат віком 1 доба були сформовані відповідно до груп курейнесучок. Курчата одержували стандартний корм. У наступному досліді курчатам добового віку одноразово вводили 1 мг вітаміну Е, що відповідає десятикратній дозі [3; 5].

Проводили полярографічні дослідження процесів дихання в мітохондріях печінки, які одержували методом диференційного центрифугування. Сукцинат використовували як субстрат окиснення, а 2,4-динітрофенол (2,4-ДНФ) - як роз'єднувач процесів дихання і фосфорилювання. Швидкість поглинання кисню визначали за допомогою кисневого електрода Кларка. Розраховували швидкості дихання мітохондрій $\left(\mathrm{V}_{2}\right.$, $\mathrm{V}_{3}, \mathrm{~V}_{4}, \mathrm{~V}_{\text {днф}}$ ), інтенсивність фосфорилювання (IФ), коефіцієнт дихального контролю за Ларді (ДК) та ефективність фосфорилювання (АДФ/О) [3].

Концентрацію вітаміну Е визначали за допомогою ТШХ. Активність ферменту СДГ (КФ.1.3.5.1.) досліджували за методом Ф. Є. Путіліної та Н. Д. Сщєнко з модифікаціями [2; 3]. Математичне опрацювання результатів проведено 3 використанням комп'ютерних таблиць Excel.

Результати дослідження. Застосування підвищених доз вітаміну Е в раціоні курей впродовж 40 днів привело до накопичення його в печінці курей, яєчному жовтку й печінці отриманих курчат (табл. 1). Після згодовування добавок вітаміну Е куркам-несучкам у дозах - 100 і 200 мг/кг корму, концентрація вітаміну Е в печінці курчат 3-ї і 4-ї груп підвищувалася, відповідно, в 3,4 і 18,6 разів, порівняно 3 контрольною групою.

\section{1. Вплив споживання вітаміну Е курками-несучками на вміст цих вітамінів у ясчному жовтку і печінці курчат, $M \pm m(n=15)$}

\begin{tabular}{|c|c|c|c|}
\hline Групи & $\begin{array}{c}\text { Добавка вітаміну Е, } \\
\text { мг/кг }\end{array}$ & $\begin{array}{c}\text { Концентрація вітаміну Е } \\
\text { в яєчному жовтку, мкг/г }\end{array}$ & $\begin{array}{c}\text { Концентрація вітаміну Е } \\
\text { в печінці курчат, мкг/г }\end{array}$ \\
\hline 1 & 10 & $80,82 \pm 7,55$ & $253,11 \pm 5,04$ \\
\hline 2 & 0 & $64,80 \pm 3,42$ & $233,31 \pm 18,04^{*}$ \\
\hline 3 & 100 & $600,03 \pm 45,98^{* *}$ & $860,00 \pm 46,32^{* *}$ \\
\hline 4 & 200 & $1016,00 \pm 103,86^{*}$ & $4730,02 \pm 276,26^{* *}$ \\
\hline
\end{tabular}

Примітка: * - $<<0,05 ; * *-p<0,01$ - різниця достовірна порівняно з показниками 1-ї групи 
ВЕТЕРИНАРНА МЕДИЦИНА

\section{2. Вплив споживання вітаміну Е курками-несучками на дихальну активність мітохондрій печінки добових курчат, $M \pm m(n=5)$}

\begin{tabular}{|c|c|c|c|c|}
\hline \multirow{2}{*}{$\begin{array}{c}\text { Показники } \\
\text { окиснення, } \\
\text { (нмольО }\end{array}$ /хв $\times$ мг) } & \multicolumn{4}{|c|}{ Групи курчат } \\
\cline { 2 - 5 } & 1 & 2 & 3 & 4 \\
\hline $\mathrm{V}_{2}$ & $23,03 \pm 3,21$ & $13,65 \pm 0,32$ & $16,60 \pm 0,20$ & $23,16 \pm 0,02$ \\
\hline $\mathrm{V}_{3}$ & $59,86 \pm 5,14$ & $48,89 \pm 1,48$ & $57,18 \pm 0,61$ & $89,47 \pm 0,67 *$ \\
\hline $\mathrm{V}_{4}$ & $32,89 \pm 2,19$ & $16,51 \pm 0,11^{*}$ & $21,52 \pm 0,10^{*}$ & $78,95 \pm 1,01^{*}$ \\
\hline $\mathrm{V}_{\text {днф }}$ & $64,50 \pm 2,85$ & $31,46 \pm 3,50$ & $42,73 \pm 0,13$ & $98,48 \pm 4,33$ \\
\hline ДК $\left(\mathrm{V}_{3} / \mathrm{V}_{2}\right)$, од. & $2,60 \pm 0,35$ & $3,58 \pm 0,03$ & $3,46 \pm 0,05$ & $3,86 \pm 0,06$ \\
\hline
\end{tabular}

Примітка: * - p<0,05; ** - p<0,01 - різниця достовірна порівняно з показниками 1-ї групи

Після застосування добавок вітаміну Е (100 i 200 мг/кг) у раціоні курей протягом 40 днів у отриманих курчат у віці 1 доба встановлено стимуляцію окиснення сукцинату мітохондріями печінки (табл. 2). Так, у курчат 4-ї групи відбувалося значне підвищення швидкості окиснення сукцинату, швидкість $\mathrm{V}_{3}$ перевищувала показник контрольної групи на $49,5 \%(\mathrm{p}<0,05)$, а швидкість $\mathrm{V}_{4}$ збільшувалася в 2,4 разу.

Важливо відзначити, що в 4-й групі курчат швидкість окиснення в роз'єднаному стані, $\mathrm{V}_{\text {днф, }}$ була найвищою в даному досліді, до того ж ДК за Ларді збільшувався на 48,5 \%. Показник ДК за Ларді відображає реакцію мітохондрій на екзогенний АДФ і, ймовірно, необхідність в АТФ. Відомо, що підвищення інтенсивності окиснення сукцинату відбувається під дією несприятливих чинників на мембрани мітохондрій. Ймовірно, підвищення швидкості $\mathrm{V}_{\text {днф }}$ У разі окиснення сукцинату в 7-й групі курчат можна вважати відображенням «стресового» впливу високої концентрації вітаміну Е в печінці на дихальну активність мітохондрій.

У процесі окиснення сукцинату у курчат 4-ї групи встановлене підвищення показника ІФ на $14,6 \%$, але ефективність фосфорилювання АДФ/О знижувалась. У курчат 3-ї групи (доза вітаміну Е в раціоні курей - 100 мг/кг) встановлено загальне зниження дихальної активності мітохондрій, що супроводжувалося зниженням АДФ/О на $35,7 \%$.

У результаті застосування в раціоні курейнесучок вітаміну Е в 10- і 20-кратних дозах він спричиняє несприятливий вплив на дихальну активність мітохондрій печінки курчат добового віку, оскільки за окиснення сукцинату процеси тканинного дихання і фосфорилювання роз'єднуються.

В результаті дії ліпотропних роз'єднуючих агентів, наприклад 2,4-ДНФ, тканинне дихання стає неконтрольованим або відбувається 3 максимальною швидкістю. Так, як 2,4-ДНФ прони- кає крізь внутрішню мембрану мітохондрій у вигляді іону ( $\left.\mathrm{PhO}^{-}\right)$або фенолу $(\mathrm{PhOH})$, транспортуючи в матрикс $\mathrm{H}^{+}$. Можливо, вітамін $\mathrm{E}$, який також має у структурі фенольне угрупування, здатен у великих концентраціях діяти як протонофор. Тобто, у «надлишковій» концентрації вітамін Е, який не витрачається як антиоксидант, може впливати на транспортування протонів $\mathrm{i}$ змінювати заряд мембрани, порушуючи протонний градієнт, необхідний для синтезу АТФ. Результатом такої дії є вільне окиснення субстрату, не сполучене з утворенням АТФ.

У наступному досліді на курчатах добового віку визначали показники дихальної активності мітохондрій за одноразового перорального введення в організм десятикратної дози вітаміну $\mathrm{E}$ та динаміку накопичення альфа-токоферолу в печінці. Пік концентрації вітаміну Е в плазмі крові та в печінці курчат наступав одночасно, через 4 години після введення препарату (рис. 1). У плазмі крові концентрація вітаміну Е збільшувалася $з 9,77 \pm 0,84$ мкг/мЛ до $34,33 \pm 2,56$ мкг/мл, а в печінці - 3 362,64 $\pm 7,80$ мкг/Г до 728,12 $\pm 12,27$ мкг/Г $(\mathrm{p}<0,01)$. Такий ефект був короткочасним, рівень вітаміну Е відновлювався впродовж дев'яти годин.

У курчат, протягом 6-ї годин після введення вітаміну Е, встановлене нерівномірне зростання швидкості окиснення сукцинату. Дихальна активність мітохондрій печінки змінювалася вже через годину (рис. 2). Максимальне підвищення швидкостей окиснення сукцинату визначено через 4 години після введення вітаміну Е.

Так, на 4-й годині досліду швидкість $\mathrm{V}_{3}$ збільшувалася в 3,2 разу, а $\mathrm{V}_{\text {днф }}$ - в 3,4 разу. Встановлене незначне зростання ступеня сполучення реакцій дихання і фосфорилювання: впродовж першої години досліду ДК за окиснення сукцинату зростав від $2,06 \pm 0,04$ до $2,34 \pm 0,20$ од., через 4 години цей показник складав 2,56 $\pm 0,09$ од. Такі зміни супроводжувалися підвищенням показни- 


\section{ВЕТЕРИНАРНА МЕДИЦИНА}

ків ІФ у 3,3 разу (рис. 3) за майже сталого відношення АДФ/О (рис. 4). Це свідчить про загальну стимуляцію окиснення сукцинату мітохондріями в разі збільшення концентрації вітаміну Е в печінці більше ніж у удвічі. Зокрема, більш активно проходили реакції вільного окиснення, а процеси утворення АТФ відбувалися швидко, хоча й малоефективно.

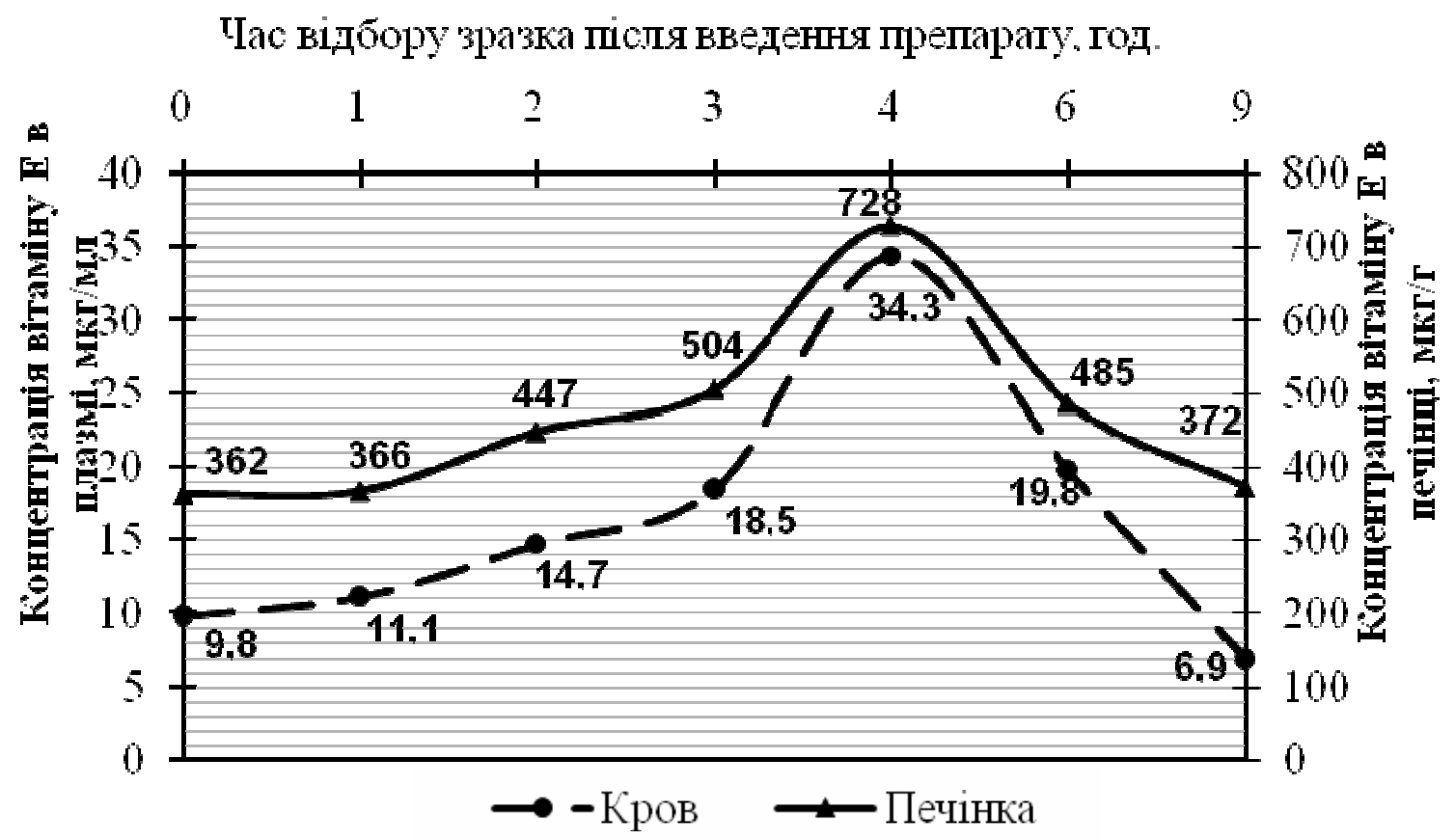

Рис. 1. Динаміка накопичення вітаміну Е у плазмі крові курчат після введення препарату
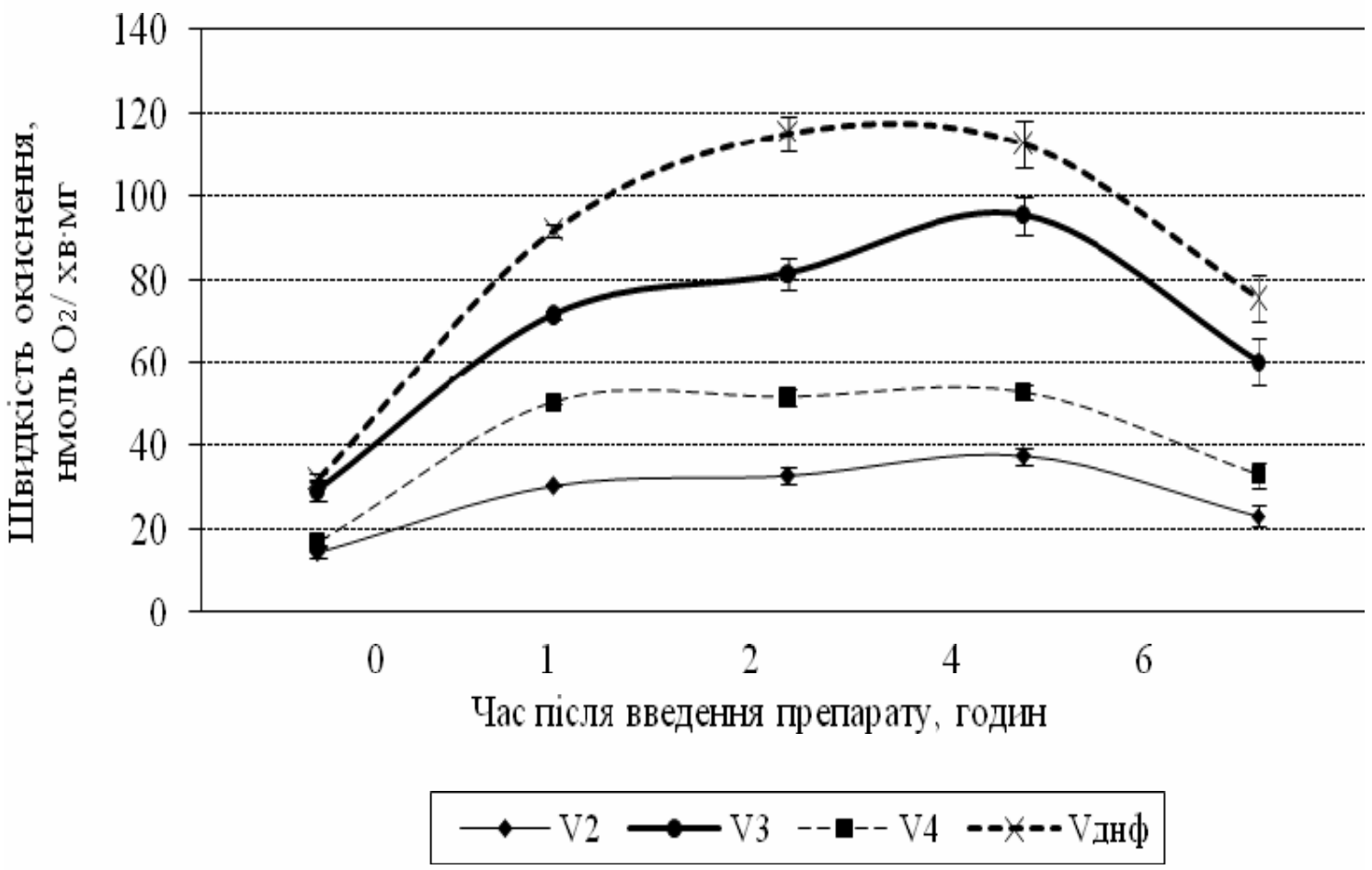

Рис. 2. Динаміка окиснення сукцинату мітохондріями печінки курчат після перорального введення вітаміну $Е$ 


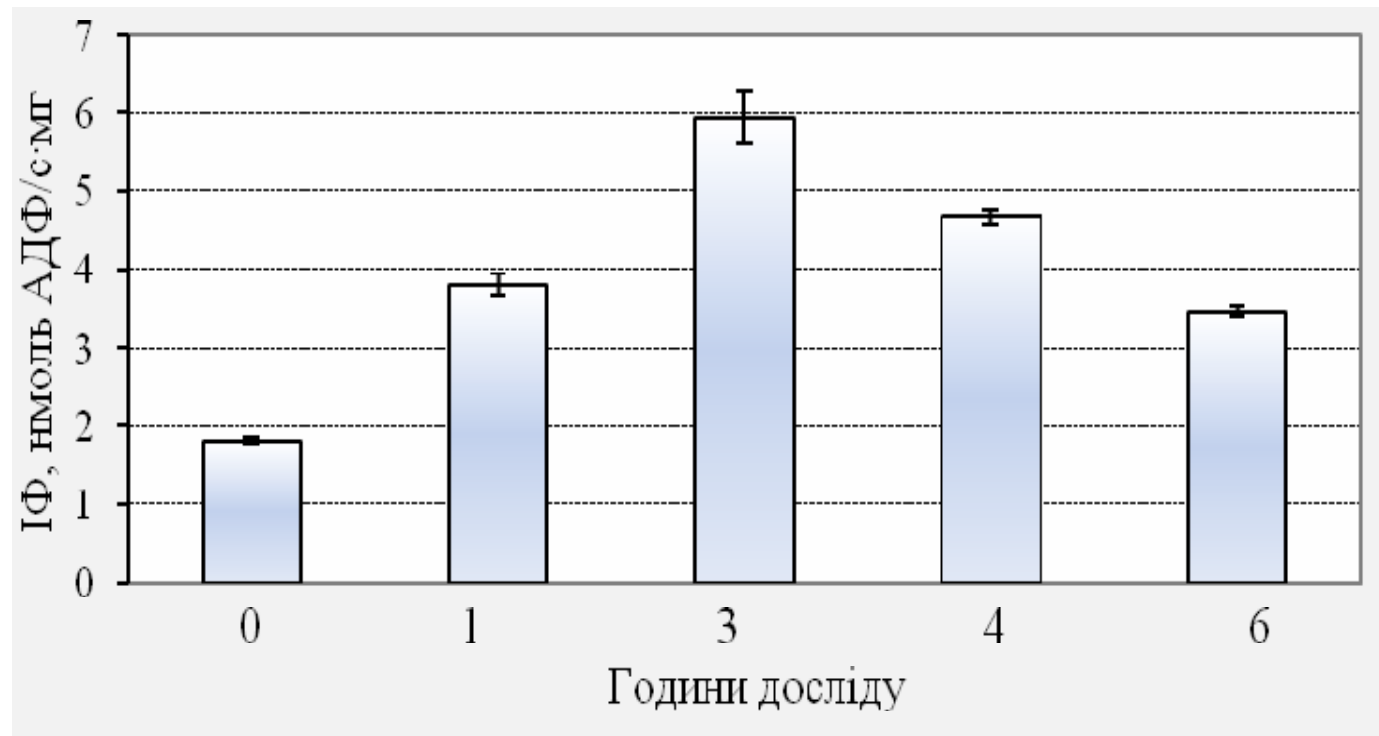

Рис. 3. Динаміка інтенсивності фосфорилювання в мітохондріях печінки курчат після одноразового введення вітаміну $E$

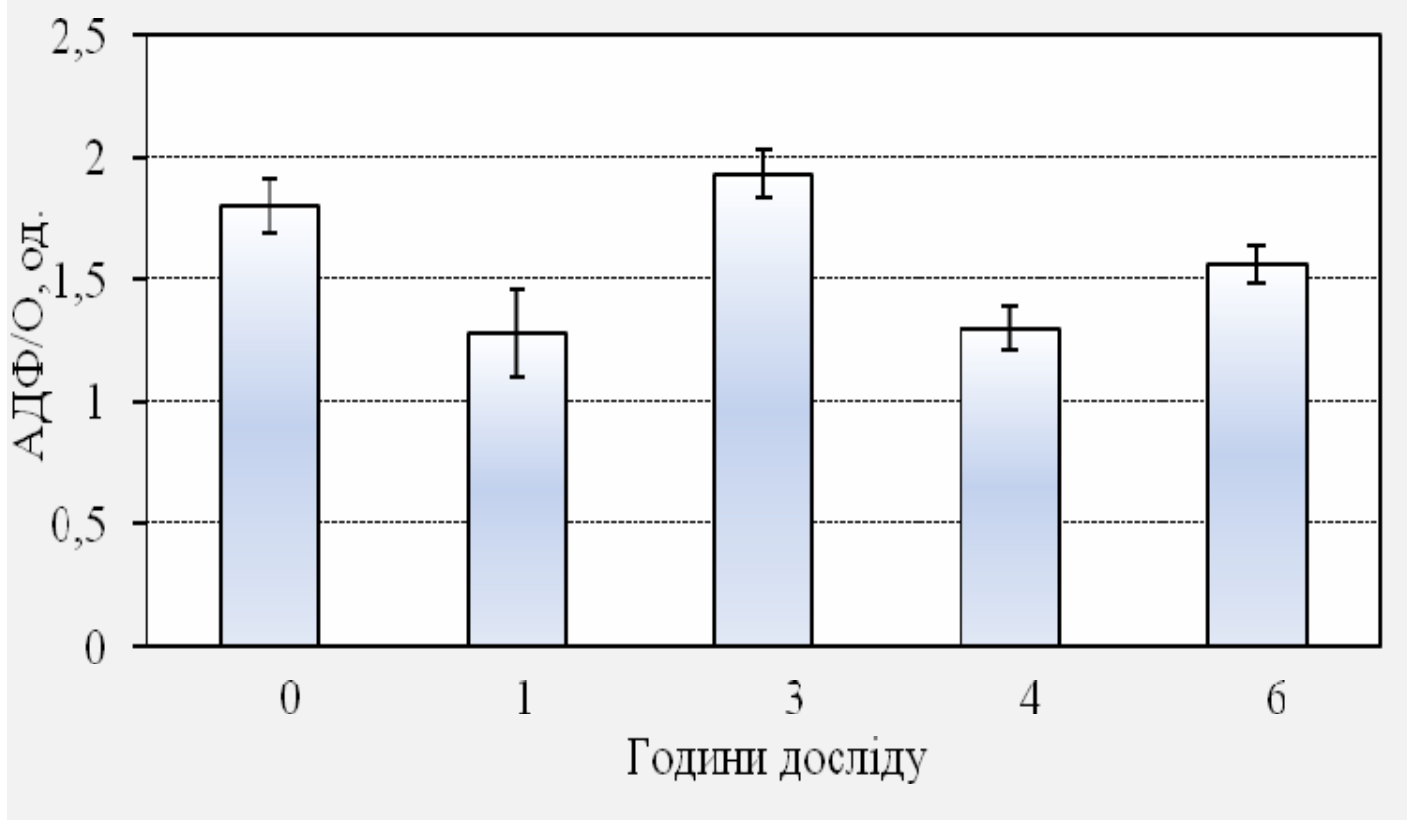

Рис. 4. Ефективність фосфорилювання в мітохондріях печінки курчат після одноразового введення вітаміну $E$

У курей-несучок, яким впродовж 40 днів згодовували корми, збагачені вітаміном Е, визначали показники тканинного дихання, а також активність ферменту СДГ у мітохондріях печінки. За застосування вітаміну Е в раціоні курей у кількості 100 мг/кг активність ферменту СДГ у печінці збільшилася від 1,796 до 2,326 мкМоль/мгхгод ( $<00,05)$. Вірогідно, активізація СДГ в печінці курей $\epsilon$ неспецифічною в результаті реакції мітохондрій на дію вітаміну Е як мембранотропного фактора.
У 3-й групі курей (доза 100 мг/кг) швидкість $\mathrm{V}_{2}$ підвищилась на $78,9 \%(\mathrm{p}<0,05)$, ІФ суттєво не змінилась, але АДФ/О збільшився від 1,23 од. (в контролі) до 1,94 од. У курей 4-ї групи за збільшення дози вітаміну Е до 200 мг/кг корму та зростання його концентрації в печінці в 9,5 разу інтенсивність окиснення сукцинату $\mathrm{V}_{2}$ підвищилася на $115,4 \%$; встановлено незначне підвищення коефіцієнта АДФ/О, водночас зі збільшенням ІФ на $12,4 \%$. Такі зміни є відображенням стимулюючої дії вітаміну Е в 10- і 20- 


\section{ВЕТЕРИНАРНА МЕДИЦИНА}

кратних дозах на процеси дихання та окислювального фосфорилювання в мітохондріях печінки в разі споживання його птицею впродовж 40 днів. Стимулюючий вплив вітаміну Е на окиснення сукцинату мітохондріями печінки курей, окрім мембранотропної дії, може бути також відображенням міжвітамінних взаємодій убіхінону (компоненту III комплексу ДЛ) та токоферолу [4].

Подальше накопичення (60 днів) у печінці курей вітаміну $\mathrm{E}$ за споживання у таких дозах спричиняє зниження дихальної активності мітохондрій і роз'єднання процесів дихання та фосфорилювання, що виявилося порушенням використання екзогенного АДФ та уповільненням синтезу АТФ за окиснення сукцинату. Це узгоджується 3 даними літератури про застосування високих доз вітаміну Е в раціоні курей [12].

Показники ІФ і АДФ/О значно знижувались у курей 4-ї групи, які одержували дозу вітаміну Е - 200 мг/кг. Так, ІФ зменшився від 1,69 (у контролі) до 0,98 (нмоль АДФ/с× АДФ/О - від 1,02 до 0,80 од. Це відображає несприятливий вплив вітаміну Е на реакції дихання та фосфорилювання в разі окиснення сукцинату за умов тривалого накопичення альфатокоферолу в печінці курей.

У цілому, на основі отриманих результатів діходимо висновку, що вітамін Е спричиняє дозозалежні ефекти на реакції біологічного окиснення в печінці курей і курчат. Незважаючи на шляхи накопичення вітаміну $\mathrm{E}$ в печінці (тривале збагачення раціону курей, перехід з яєчного жовтку в печінку курчати, одноразове пероральне введення альфа-токоферилацетату), зміни у процесах окиснення сукцинату мітохондріями під дією вітаміну Е відбувались однотипно і залежно від його дози та концентрації в печінці.

3 метою активізації ферментативної активності мітохондрій печінки та активізації окиснення субстратів ЦТК вітамін Е можна застосовувати в раціоні курей у кількості 100 мг/кг корму не більше 35-40 днів. У разі такої корекції раціону можна стимулювати енергетичний обмін у птиці, а також отримати яйця, збагачені вітаміном Е. Проте для отримання інкубаційних яєць не слід перевищувати дозу вітаміну Е для курей більше, ніж 100 мг/кг корму, так як активізація вільного

\section{БІБЛІОГРАФІЯ}

1. Басанкин А. В. Фармако-токсикологическое обоснование применения янтарной кислоты в животноводстве и ветеринарии: дисс... кандидата вет. наук: спец. 16.00.04 «Ветеринарная фармакология с токсикологией» / Алексей Вадимович Басанкин. - Казань, 2007. - 142 с. окиснення сукцинату в печінці курчат $є$ несприятливим чинником на початку росту.

Висновки. Зміни дихальної активності мітохондрій та процесів фосфорилювання за окиснення сукцинату залежать від дози вітаміну Е й пов'язані з його вмістом у печінці.

1. Зростання концентрації вітаміну Е в печінці добових курчат більше ніж у 3,4 разу, внаслідок його попереднього накопичення в яйці, спричиняє негативний вплив на енергетичні процеси у мітохондріях, оскільки за інтенсивного окиснення сукцинату відбувається зниження ефективності фосфорилювання.

2. Одноразове пероральне введення курчатам 1 мг вітаміну Е спричиняє короткочасну стимуляцію вільного окиснення сукцинату, а процеси дихання і синтезу АТФ роз'єднуються.

3. Вплив вітаміну Е на окиснення сукцинату у мітохондріях печінки курей виявляється залежно від його дози в раціоні й термінів накопичення в організмі. Вітамін Е (у дозах 100 і 200 мг/кг за накопичення в організмі курей протягом 40 днів) має позитивний стимулюючий вплив на окиснення сукцинату і процеси фосфорилювання у мітохондріях печінки.

4. Довготривале застосування вітаміну Е в 10i 20-кратних дозах у раціоні курей-несучок (упродовж 60 днів недоцільне), оскільки спричиняє гальмування окиснення сукцинату в мітохондріях печінки.

5. Стимуляцію вільного окиснення сукцинату в мітохондріях печінки курчат під дією високих доз вітаміну Е в раціоні важливо враховувати в разі можливого сумісного застосування вітаміну Е і сукцинату, як факторів метаболічної корекції у процесі вирощування птиці.

Перспективи подалыших досліджень. У зв'язку 3 мембранотропною та антиоксидантною функціями вітаміну Е необхідне подальше вивчення його впливу на енергетичні процеси в печінці за умов введення у раціон тварин екзогенних субстратів тканинного дихання. За одночасного застосування сукцинату і вітаміну Е у раціоні птиці важливо дослідити їх дозозалежні ефекти на реакції біологічного окиснення. Такі розробки сприятимуть ефективному проведенню заходів метаболічної корекції та метаболічної терапії.

2. Биохимические методы контроля метаболизма в органах и тканях птиц и их витаминной обеспеченности (научно-методические рекомендации) / П. Ф. Сурай, И. А. Ионов. - Х. : Юж. отд. ВАСХНИЛ УНИИП, 1990. - 138 с.

3. Критерии и методы контроля метаболизма в 


\section{ВЕТЕРИНАРНА МЕДИЦИНА}

организме животных и птиц / И. А.Ионов, С. О. Шаповалов, Е. В. Руденко [и др.] - Х. : Институт животноводства НААН, 2011. - 376 с.

4. Кучменко О. Б. Розробка біологічно активних комплексів для корекції показників біоенергетичних процесів за умов вітамін Е-гіповітамінозу / О.Б. Кучменко, Г. В. Донченко, Д. М. Петухов // Вісник БДАУ. - 2009. - Вип. 60. - Ч. 1. - С. 78-81.

5. Лемешева М. М. Кормление сельскохозяйственной птицы / М. М. Лемешева. - Сумы : Слобожанщина, 2003. - 152 с.

6. Московцева О. М. Влияние янтарной кислоты и ее производных на состояние свободнорадикальных процессов экспериментальных животных: дисс. ... кандидата биол. наук: спец. 03.00.00 «Биологические науки» / О.М. Московцева. - Нижний Новгород, 2006. - 160 с.

7. Саакян И. Р. Активация и ингибирование сукцинатзависимого транспорта $\mathrm{Ca}^{2+}$ в митохондрии печени при развитии адаптационных реакций / И. Р. Саакян, С. Г. Саакян, М. Н. Кондрашова // Биохимия. - 2001. - Т. 66. - Вып. 7. - С. 976-984.

8. Современные аспекты метаболической коррекции / И. С. Чекман, В. С. Сухоруков, И. В. Ле- онтьева [и др.] // Здоров’я України. - 2007. - № 7. - C. 12.

9. Трунов М. А. Действие и применение препарата ЯК-85 в птицеводстве: дисс. ... канд. вет. наук: спец. 16.00.03, 16.00.04 «Ветеринарная микробиология, вирусология, эпизоотология, микология и иммунология» / М. А. Трунов. - Краснодар, $2000-156 \mathrm{c}$.

10. Bergö $M$. Antioxidants in the diet can worsen cancer [Electronic Resource] / M. Bergö, P. Lindahl // Pressrelease. - University of Gothenburg, 2014. http://www.expertsvar.se/english/pressrelease?press ReleaseID $=21763$ \&languageID $=2-$ Title from the screen (дата обращения: 17.02.2014).

11. Higdon J. Vitamin E [Electronic Resource] / J. Higdon, V. J. Drake, M. G. Traber // Linus Pauling Institute, Micronutrient Information Center, Oregon State University. - Copyright 2008. - Mode of access : URL : http://lpi.oregonstate.edu/ infocenter/vitamins/vitaminE/. - Title from the screen (дата обращения: 23.01.2014).

12. Surai $P$. F. Vitamin E and avian reproduction / P. F. Surai // Poultry and avian biology reviews. 1999. - V. 10, № 1. - P. 3-60. 